Вісник Львівського університету. Серія філос.-політолог. студіі. 2019. Випуск 27, с. 87-92

Visnuk of the Lviv University. Series Philos.-Political Studies. Issue 27, p. 87-92

UDC 327.57

DOI https://doi.org/10.30970/2307-1664.2019.27.11

\title{
INFLUENCE OF THE TERRITORIAL FACTOR ON THE INTERNATIONAL POSITION OF AZERBAIJAN
}

\author{
Mammad-zade Nargiz Sabir \\ Baku State University, \\ Department of International Relations \\ Akademika Zakhida Khalilova str., 23, AZ1148, Baku, Azerbaijan
}

The main priority issue of modern Azerbaijan is the policy of ensuring territorial integrity. At the same time, Azerbaijan is also strengthening its position in the international arena. This article explores the territorial factor as affecting the international position of the Azerbaijani state.

Azerbaijan throughout its history has repeatedly faced a territorial problem and today this issue is on the agenda. From time immemorial, the lands of Azerbaijan have been interesting and attractive to many actors of international relations. Azerbaijan is located in the Caucasus region, combines strategic transport routes (Great Silk Road, oil and gas pipelines, roads), and has natural resources, the struggle for which continues today.

The territorial factor in the foreign policy of the Republic of Azerbaijan is presented today by the Armenian-Azerbaijani Nagorno-Karabakh conflict. After many years of discussion, the legal status of the Caspian Sea has been determined, which is strategically important for Azerbaijan, both politically and economically.

The territorial factor and, most importantly, the problem of ensuring the territorial integrity of the Republic of Azerbaijan have a real impact on its international position. This is expressed in the interests that are in relation to our country, which attracts with its resources.

The loss of historical lands became the main topic in the international politics of an independent Azerbaijan state. Modern Azerbaijan today seeks to pursue a multi-vector policy and balances the interests of its neighbors and Western countries. This course has been successfully implemented since the early 2000s. But, first it is necessary to remember the interests of the world states in Azerbaijan.

Thus, in connection with the above arguments, as well as the economic interest of the world powers in our country and in the region suggests that the influence of the territorial factor on the international position of the Republic of Azerbaijan is indisputable. In addition, ensuring territorial integrity has been and remains a pressing issue for our state.

Key words: Republic of Azerbaijan, territory, international position, modern states, system of international relations, Caspian Sea, economic aspects, territorial factor, national interests, resources.

At the present stage, for all states, all sorts of factors that influence their international position determine their role and place in the system of international relations are a pressing issue in their development. One of these is the territorial factor. Today this problem concerns almost any country whose territory is of any political or economic interest. The territory of the modern state has not lost its relevance even in the conditions of the formation of a certain global space, the formation of which is preached by the processes and scenarios of globalization that have become a characteristic feature of the foreign policy of the leading powers. The desire of world political players to create a unified world through the unification of cultures, the creation of a universal global financial system with the participation of international financial structures, strengthening the positions of transnational companies that are a threat to the nation state, is unable to force the current states to give up their historical lands, as evidenced by the ongoing territorial conflicts

(C) Mammad-zade Nargiz Sabir, 2019 
and military operations in various regions of the world, the purpose of which, in most cases, is to on the territory of a State. In these new conditions of international development, each modern state builds its foreign policy in such a way as to preserve its territory, but, at the same time, be able to avoid being involved in the provocative game of interested parties.

Interests of participants of international relations in Azerbaijan

As for our state, Azerbaijan throughout its history has repeatedly encountered a territorial problem and today this issue is on the agenda. From time immemorial, the lands of Azerbaijan have been interesting and attractive to many actors of international relations. Azerbaijan is located in the Caucasus region, combines strategic transport routes (Great Silk Road, oil and gas pipelines, roads), and has natural resources, the struggle for which continues today.

The territorial factor in the foreign policy of the Republic of Azerbaijan is presented today by the Armenian-Azerbaijani Nagorno-Karabakh conflict. After many years of discussion, the legal status of the Caspian Sea has been determined, which is strategically important for Azerbaijan, both politically and economically.

The loss of historical lands became the main topic in the international politics of an independent Azerbaijan state. Modern Azerbaijan today seeks to pursue a multi-vector policy and balances the interests of its neighbors and Western countries. This course has been successfully implemented since the early 2000s. But, first it is necessary to remember the interests of the world states in Azerbaijan.

"The strategic position of Azerbaijan in the Caucasus region and on the historic Silk Road has led to the important role of the states of the region in international relations, diplomatic and trade relations for a long time" [2]. "Besides other countries of the East, Azerbaijan has managed to establish wide diplomatic relations with European states. At the end of the twentieth century, Azerbaijan, having regained its independence as a result of the collapse of the USSR, was faced with the need to build its foreign policy activities. Based on the historical heritage and peculiarities of the geopolitical position of Azerbaijan, a multi-vector and balanced foreign policy strategy has been formed, which continues successfully today, based on the national interests of Azerbaijan, in accordance with the challenges and demands of the time" [2].

As regional states - Russia, Iran, Turkey, naturally, show the greatest interest in Azerbaijan.

At the turn of the century, one of the main arenas of the clash of two socio-cultural civilizations became the Trans Caucasus. And Russia's attempt to significantly expand the territorial range of the confrontation to the Middle East through active involvement in the Syrian and Libyan cauldron could not stop Western political expansion in the post-Soviet space. For Azerbaijan and Russia, the stumbling block in the development of allied relations is the Karabakh conflict and the factor of Armenia. Russia due to historical circumstances is connected with Armenia by allied obligations. However, Azerbaijan today is strengthening its military-political alliance with Russia. The solid foundation of this cooperation is the trusting relations of the heads of state, which contribute to the resolution of many situations and the development of new models both within the framework of bilateral relations and for the formation of a system of regional policy. Evidence of such a rapprochement and mutual understanding is the success of the last historical summit of the Caspian littoral countries, which will influence the implementation of projects that open the way to the development of the entire region. It was thanks to the presidents of Azerbaijan and Russia that the eternal Caspian dispute was resolved, which fairly and with the interests of their countries provided the Caspian with new legal status.

It was Azerbaijan and Russia that stood at the origins of the global transport and communications artery within the North-South project, which will connect northern Europe with India and Southeast Asia (Azerbaijan completed all work on its section of this international corridor) [3]. 
A historical agreement has been reached between Azerbaijan and Russia on the development of a railway communication project on the Baku-Tbilisi-Kars route. Azerbaijan is becoming an outlet for Russia to the Big Asia. In turn, for Azerbaijan, Russia has become a window into "unlimited Eurasian space, into socio-culturological integration, scientific progress, advanced military technologies and political modernism. The close ties of the partnership and union allowed the Russian state powers and national patriots to declare Azerbaijan the only ally of Russia in the Caucasus" [3].

As for Iran, which is also the leading regional state, for the last period the relations are actively manifested in a trilateral format: Russia, Iran and Azerbaijan. The parties intend to cooperate on a wide range of issues, including the energy market, mutual trade, ecology, transport, as well as international policy. The next summit is scheduled for August of this year. The trilateral format of relations between regional states is perceived as a very good initiative, in which all parties are interested. Within the framework of the summits, the heads of state agreed on joint efforts to further enhance trade and economic relations create favorable conditions for the development of trade and mutual investments. The priority areas of cooperation were taken industry, energy, transport, agriculture, financial and banking sector and the field of customs regulation. Special attention is paid to cooperation in the field of road, rail and air transport in order to modernize the transport infrastructure and develop the international North-South transport corridor. In this regard, the parties spoke of the need for the speedy implementation of the project for the construction of the Rasht-Astara railway line in Iran.

As for cooperation in the Caspian, it is aimed at cooperation of port administrations, maritime shipping, multimodal transportation, sea tourism, conservation of aquatic biological resources, environmental protection, energy, trade, economics, research, hydrography, meteorology, safety and military cooperation, warning and emergency prevention.

Turkey is the first country to recognize the independence of Azerbaijan in both 1918 and 1991. Unlike Russia and Iran, with Azerbaijan, Azerbaijan had no stages of confrontation. However, for Turkey, Azerbaijan is interesting both politically and economically. Azerbaijan is a strategic partner of Turkey, which in almost all areas supports the independence of our state both at the regional and global levels.

The development of the transport system has turned Azerbaijan into a major transit and logistics center. And this fact naturally attracted the attention of all regional powers, including Turkey. Modernization of the railway infrastructure attracted the attention of Turkey, and it became a full participant in projects in this direction. "Improving the operation of the Baku-Tbilisi-Kars railway, the North-South, South-West transport corridors, and the Trans-Caspian international transport route is aimed at increasing the transit potential of the participants in these projects“" [5].

Speaking about the interests of Turkey in Azerbaijan, it is necessary to note the interest of both parties in military cooperation. In this area, Turkey is interested in Azerbaijan's partnership.

The main aspects of Azerbaijan's foreign policy at the present stage

"Azerbaijan's foreign policy in the region and beyond is permeated with the spirit of good neighborliness, mutually beneficial cooperation and partnership. Without entering the military-political blocs, Azerbaijan has created an atmosphere of "soft" security, acting not as a "consumer", but as a "producer" and guarantor of security in the region, and today is perceived as a worthy and reliable partner. In the words of political theorist Joseph Nye, the policy pursued by Azerbaijan could be called Smart Power. On the other hand, conducting an independent foreign policy in such a complex region and in a chaotic world order, in the crucible of political, economic, military crises, and successfully ensuring despite all its security, it would probably be more correct to call Intelligent Power. Azerbaijan actively supports the efforts of the international community 
on a bilateral and multilateral basis, aimed at strengthening international security, overcoming conflicts that serve as fertile ground for terrorism, radicalism and extremism, and the proliferation of weapons of mass destruction. Azerbaijan also contributes to the strengthening of existing international mechanisms and means in this direction and increasing their effectiveness. Azerbaijan is in favor of building a system of international relations based on the rule of law, and supports efforts aimed at that" [2].

At the turn of the century, independent Azerbaijan faced major problems that did not allow its territorial integrity and international security to be ensured at the initial stages. Regional and world powers did not want to accept the political independence of our state and, pushing away our foreign policy, tried to secure only their geopolitical, economic interests. There was an attempt at a coup d'état and the fall of sovereignty in our country. The existence of territorial problems, namely, the unresolved legal status of the Caspian Sea and the Armenian-Azerbaijani Nagorno-Karabakh conflict, in principle, did not perceive Azerbaijan as an independent participant in international relations. However, in the future the situation has changed. Azerbaijan has managed to maintain its position based on national interests, and "a certain geopolitical balance has developed in the region, which consists in a balance serving the national interests of Azerbaijan" [4].

"At this stage, global geopolitical processes have intensified, and at the same time, uncertainty has increased. President Ilham Aliyev stressed that some major powers now proceed from a position of strength. Consequently, unexpected events can occur in the region at any time. Azerbaijan is ready for such situations and will always proceed from its national interests. In addition, it will not be something like a departure from its position in the interests of any superpower. Therefore, everyone should clearly and definitely know: Azerbaijan will not cede its national interests to anyone!" [4].

Thus, such a statement suggests that the Azerbaijan Republic, despite its youth and relatively little experience of independent development, at the international level declared its ability to independently solve its problems and, within the framework of international law and international standards of cooperation, is ready and able to be a full member of the world, politicians in a very complex and contradictory conditions for the formation of a new system of international relations.

The above arguments allow us to state that the territorial factor and, most importantly, the problem of ensuring the territorial integrity of the Republic of Azerbaijan have a real impact on its international position. This is expressed in the interests that are in relation to our country, which attracts with its resources. Evidence of this can be numerous foreign investments in the country's economy, agreements and agreements with international opponents.

However, the impossibility of using the entire territory, for $20 \%$ are in the zone of occupation, creates obstacles in both political and economic spheres, and this, in turn, affects the international position of our country. Since a certain part of the country is beyond the overall development and recovery requires time and money. This situation goes beyond the internal policy of the Azerbaijani state. For more than thirty years, the territorial issue has been the main priority in the foreign policy of Azerbaijan. Characteristic in this matter is the participation of third countries and international organizations. As for the territory of Nagorno-Karabakh, the relevant international structures have adopted numerous resolutions recognizing territorial integrity within the framework of international legal norms (UN resolutions, decisions of summits, decisions of the OSCE Minsk Group mediation).

The position of neighboring countries, which maintain international legal norms and hold the view that the conflict should not be brought to a military solution, is also extremely clear. For it will affect the situation in the region both in the political and economic direction. The conflict 
situation will exacerbate tensions in the region and ensuring regional security will enter a phase of anarchy and lack of control. In addition, this cannot be beneficial for regional countries and world powers as a whole. The aggravation of the conflict will disrupt the execution by our state of strategic projects in which considerable financial resources of their participants have been invested.

Thus, in connection with the above arguments, as well as the economic interest of the world powers in our country and in the region suggests that the influence of the territorial factor on the international position of the Republic of Azerbaijan is indisputable. In addition, ensuring territorial integrity has been and remains a pressing issue for our state.

\title{
References
}

1. Prezident İlham Oliyev regional təhlükəsizlik haqqında. Azərbaycan Respublikası Prezidentinin administrasiyası. Bak1, 2010. $50 \mathrm{~s}$.

2. Мамедъяров Э.М. Внешнеполитическая стратегия Азербайджана основана на национальных интересах и соответствует вызовам времени. IRS-Наследие. ПОЛИТИКА. № 5 (89). 2017. С. 16-25.

3. Новое веление истории: союз России и Азербайджана. URL://https:/haqqin.az/news (дата звернення: 30.08.2018).

4. Национальные интересы во внешней политике: Послание Президента Азербайджана миру. URL: https://azertag.az/ru/xeber (дата звернення: 22.02.2019).

5. Интересы сторон сталкивается в азербайджанских проектах. Послесловие к заявлению премьера. URL: https://haqqin.az/news (дата звернення: 11.05.2019).

6. Конвенция о правовом статусе Каспийского моря. 12 августа 2018 года.

\section{ВПЛИВ ТЕРИТОРІАЛЬНОГО ФАКТОРУ НА МІЖНАРОДНЕ СТАНОВИЩЕ АЗЕРБАЙДЖАНУ}

\author{
Мамедов-заде Наргіз Сабір кизи \\ Бакинський державний університет, \\ кафедра міжнародних відносин \\ вул. Академіка Західа Халілова, 23, АZ1148, м. Баку, Азербайджан
}

Пріоритетним питанням сучасного Азербайджану є політика забезпечення територіальної цілісності. Водночас Азербайджан також зміцнює свої позиції на міжнародній арені. Стаття досліджує територіальний фактор, що впливає на міжнародне становище Азербайджанської держави.

Азербайджан протягом усієї своєї історії не раз стикався з територіальної проблемою, і сьогодні це питання стоїть на порядку денному. 3 давніх-давен землі Азербайджану цікавили багатьох акторів міжнародних відносин і приваблювали їх. Азербайджан розташовується в Кавказькому регіоні, з'єднує стратегічні транспортні шляхи сполучення (Великий Шовковий шлях, нафто- й газопроводи, дороги), володіє природними ресурсами, боротьба за які триває й сьогодні.

Територіальний фактор у зовнішній політиці Азербайджанської Республіки представлений сьогодні вірмено-азербайджанським Нагірно-Карабаським конфліктом. Після довгих років обговорення визначено правовий статус Каспійського моря, який є для Азербайджану стратегічно важливим як у політичному, так і в економічному аспекті. Територіальний фактор, а головне, проблема забезпечення територіальної цілісності Азербайджанської Республіки чинять реальний вплив на іiі міжнародне становище. Це виражається в інтересах стосовно нашої країни, яка залучає свої ресурси.

Відзначається, що втрата історичних земель є головною темою в міжнародній політиці незалежної азербайджанської держави, так як сучасний Азербайджан сьогодні прагне проводити багатовекторну політику й урівноважує інтереси своїх сусідів і західних країн. Цей курс успішно реалізо- 
ваний з початку 2000-х років. Але насамперед необхідно пам'ятати про геополітичні інтереси деяких країн світу в Азербайджані.

Отже, у зв'язку з наведеними вище аргументами, а також економічною зацікавленістю світових держав у нашій країні й у регіоні можна припустити, що вплив територіального фактору на міжнародне становище Азербайджанської Республіки є незаперечним. Крім того, забезпечення територіальної цілісності було й залишається нагальною проблемою для Азербайджанської Республіки.

Ключові слова: Азербайджанська Республіка, територія, міжнародне становище, сучасні держави, система міжнародних відносин, Каспійське море, економічні аспекти, територіальний фактор, національні інтереси, ресурси. 